\title{
ПЕТРОЛОГИЯ РАННЕКАМЕННОУГОЛЬНЫХ БАЗАЛЬТОВ АРЕАЛЬНОГО И ТРЕЩИННОГО ВУЛКАНИЗМА МАГНИТОГОРСКОЙ МЕГАЗОНЫ
}

\author{
И. Р. Рахимов, Д. Н. Салихов \\ Институт геологии УФИЦ РАН, Уфа
}

Поступила в редакцию 11 сентября 2019 г.

\begin{abstract}
Аннотация: выполнен сравнительный анализ петрографических и петролого-геохимических характеристик раннекаменноугольных базальтов ареального (берёзовская свита) и трещинного (греховская свита) извержения в Магнитогорской мегазоне Южного Урала. Базальты характеризуются порфировой структурой с пилотакситовой и интерсертальной основной массой. Ареальные базальты имеют более древний возраст и отличаются от трещинных, связанных $c$ наложением серии раздвигов, повышенной магнезиальностью (Mg\#=46), глинозёмистостью $\left(\mathrm{Al}_{2} \mathrm{O}_{3}>16\right.$ мас. \%) и калиевостью $\left(\mathrm{K}_{2} \mathrm{O}=1,4\right.$ мас. \%). Трещчнные базальты характеризуются высокой титанистостью $\left(\mathrm{TiO}_{2}=2,7\right.$ мас. \%) и железистостью (FeO $=13$ мас. \%). Микроэлементный состав этих базальтов схож, им свойственны повышенные концентрации многих несовместимых элементов, в особенности - $\mathrm{Ba}$, Th, $\mathrm{U}, \mathrm{Pb}$, но не $\mathrm{Cs}, \mathrm{Sr}, \mathrm{Nb}$ u Ta. Анализ петрологогеохимических диаграмм показал, что изученные породы являются производными обогащёеного мантийного источника. Выявлено значимое присутствие в расплаве терригенного материала, имеющего геохимические признаки континентального происхождения. Показано, что при подъёме расплава к поверхности имели место процессы ассимиляции островодужной рамы и кристаллизационной дифференцииции, более явно выраженной в базальтах ареального извержения. Установлено, что изученные базальты подверглись неравномерному по составу и интенсивности метасоматозу, оказавшему заметное влияние на химический состав исследуемых пород. Для подборки компетентных проб по степени метасоматической изменённости были выделены 3 группь образцов. Сделан вывод, что при работе с сильно изменёнными породами для петрогенетических реконструкиий не пригодны анализы Са, а также не всегда применимы анализы Si, Mg и некоторых крупноионных литофильных микроэлементов (Cs, $R b, B a)$.
\end{abstract}

Ключевые слова: Магнитогорская мегазона, вулканизм, степень изменённости пород, субщелочные базальты, геохимя, обогащённая мантия, контаминация.

\section{PETROLOGY OF EARLY CARBONIFEROUS BASALTS OF AREAL AND FISSURE VOLCANISM IN THE MAGNITOGORSK MEGAZONE}

\author{
I. R. Rakhimov, D. N. Salikhov \\ Institute of Geology UFRC RAS, Ufa \\ Received 11 September 2019
}

\begin{abstract}
: a comparative analysis of the petrographic and petrological and geochemical characteristics of the Early Carboniferous basalts of the areal (Beryozovskiy Suite Formation) and fissure (Grekhovka Suite) eruptions in the Magnitogorsk Megazone of the Southern Urals is carried out. Basalts are characterized by a porphitic texture with a pilotaxitic and intersertal bulk. Areal basalts are more ancient in age and differ from fissure basalts associated with the series of tension cracks, increased magnesia $(\mathrm{Mg} \#=46)$, alumina content $\left(\mathrm{Al}_{2} \mathrm{O}_{3}>16 \mathrm{wt} \%\right)$ and potassium $\left(\mathrm{K}_{2} \mathrm{O}=1.4 \mathrm{wt} . \%\right)$. Fissure basalts are characterized by high tita$\operatorname{nium}\left(\mathrm{TiO}_{2}=2.7 \mathrm{wt} . \%\right)$ and iron content $\left(\mathrm{FeO}_{t}=13 \mathrm{wt} . \%\right)$. The trace element composition of these basalts is similar; they are characterized by increased concentrations of many incompatible elements, in particular,
\end{abstract}


$\mathrm{Ba}, \mathrm{Th}, \mathrm{U}, \mathrm{Pb}$, but not $\mathrm{Cs}, \mathrm{Sr}, \mathrm{Nb}$, and $\mathrm{Ta}$. The analysis of petrological and geochemical diagrams showed that the studied rocks are derivatives of an enriched mantle source. A significant presence in the melt of terrigenous material with geochemical features of continental origin was revealed. It was shown that, when the melt was rising to the surface, probably, processes of assimilation of the island-arc frame and crystallization differentiation, more pronounced in basalts of the areal eruption, took place. It was established that the studied basalts underwent metasomatism of an uneven composition and intensity, which had a noticeable effect on the chemical composition of the studied rocks. For the selection of competent samples according to the grade of metasomatic alteration, 3 groups of samples were identified. It is concluded that, when working with highly altered rocks, the analyzes of Ca are not suitable for petrogenic reconstructions, and also the analyzes of $\mathrm{Si}, \mathrm{Mg}$ and some large-ion lithophilic trace elements (Cs, Rb, Ba) are not always applicable.

Key words: Magnitogorsk Megazone, volcanism, stage of rock alteration, subalkaline basalts, geochemistry, enriched mantle, contamination.

\section{Введение}

Эффузивный магматизм раннего карбона в Магнитогорской мегазоне Южного Урала был приурочен, главным образом, к Магнитогорской рифтогенной структуре, имеющей субмеридиональное простирание (рис. 1a). На раннем этапе $\left(\mathrm{C}_{1} \mathrm{t}_{2}-\mathrm{v}_{1}\right)$ проявлялся вулканизм, связанный с ареальными излияниями лав диф- ференцированного состава. При этом объёмы основных и кислых продуктов магматизма в целом сопоставимы, реже встречаются вулканиты среднего состава. Вся совокупность этих пород, характеризующихся общим субщелочным уклоном и повышенной глинозёмистостью, отнесена к берёзовской свите [1]. Позднее $\left(\mathrm{C}_{1} \mathrm{v}_{1}-\mathrm{v}_{2}\right)$ на субмеридиональный пояс страто-
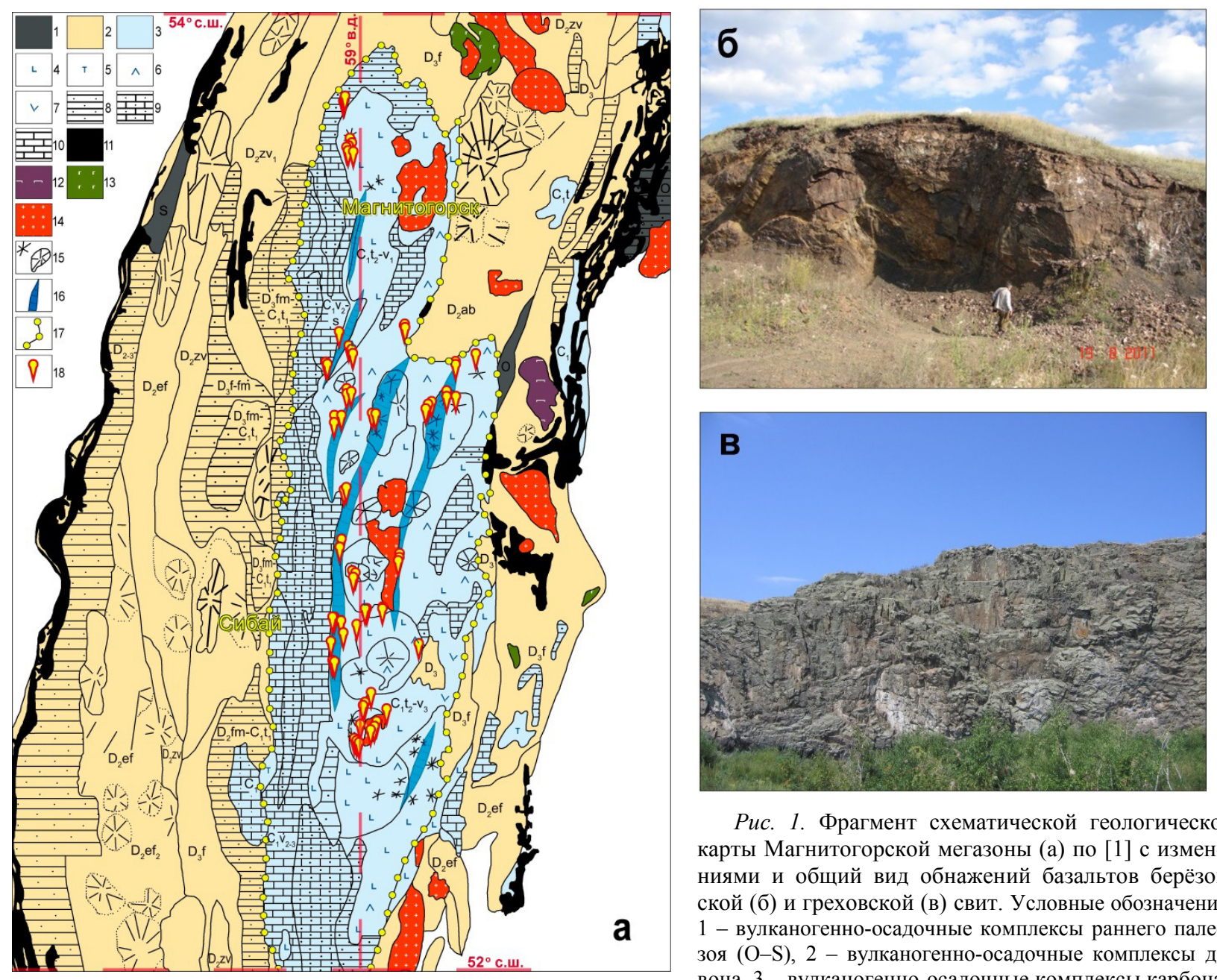

Puc. 1. Фрагмент схематической геологической карты Магнитогорской мегазоны (а) по [1] с изменениями и общий вид обнажений базальтов берёзовской (б) и греховской (в) свит. Условные обозначения: 1 - вулканогенно-осадочные комплексы раннего палеозоя $(\mathrm{O}-\mathrm{S}), 2$ - вулканогенно-осадочные комплексы девона, 3 - вулканогенно-осадочные комплексы карбона, 4 - субщелочные базальты, 5 - толеитовые базальты, 6 - трахидациты, 7 - риолиты, 8 - глинисто-терригенные породы, 9 - терригенно-карбонатные породы, 10 - карбонатные породы, 11 - гипербазиты, 12 - интрузии ультраосновного-основного состава, 13 - интрузии основного-среднего состава, 14 - интрузии кислого состава, 15 - палеовулканические постройки, 16 - палеораздвиги, 17 - граница Магнитогорской рифтогенной структуры, 18 - места отбора проб.

Примечание: фото «б» сделано близ п. Кирса, фото «в» сделано близ п. Грязнушинский. 
вулканов была наложена система раздвигов северовосточного простирания (рис. 1a), по которым в основном извергались субщелочные высокотитанистые базальты и андезибазальты, и в меньшей мере - трахидациты и субщелочные риолиты, относимые к греховской свите [2].

Изучением продуктов вулканизма раннего карбона Магнитогорской мегазоны (ММ3) занимались многие специалисты, результаты их исследований приведены в работах [3-7 и мн. др.]. Однако проблемы источника магматизма и процессов дифференциации расплава изучены недостаточно, а геодинамические обстановки проявления этих вулканитов и по сей день остаются дискуссионными. Не ясна связь ареального и трещинного вулканизма в контексте эволюции единого мантийного резервуара в процессе тектонического развития ММЗ в раннем карбоне. Цель данной статьи сравнение петрографических и геохимических особенностей базальтов ареального и трещинного вулканизма, что призвано помочь установить причины специфических геохимических характеристик базальтов и проследить их общую петролого-геохимическую эволюцию в течение раннего карбона.

\section{Методы исследований}

В рамках представленного материала было изучено не менее 50 образцов вулканитов (в том числе 6 образцов керна), отобранных из разрезов близ населённых пунктов Ершовский, Богдановское, Грязнушинкий, Обручёвка, Черноотрог Челябинской области (точки опробования показаны на рис. 1). Петрографическое описание проводилось на поляризационном микроскопе Axioskop 40 Carl Zeiss.

Макроэлементный состав был получен рентгенофлуоресцентным методом на спектрометре VRA-30 Carl Zeiss, а также силикатным методом в Институте геологии УФИЦ РАН (Уфа). При анализе использовалась рентгеновская трубка с $\mathrm{W}$-анодом (30-40 кВ, 40 мА). Предел обнаружения при измерении $\mathrm{SiO}_{2}, \mathrm{Al}_{2} \mathrm{O}_{3}$ составлял 0,1 мас. \%, $\mathrm{TiO}_{2}, \mathrm{Fe}_{2} \mathrm{O}_{3}, \mathrm{MnO}, \mathrm{CaO}, \mathrm{K}_{2} \mathrm{O}$, $\mathrm{P}_{2} \mathrm{O}_{5}$, Аобщ - 0,01мас. \%, $\mathrm{MgO}-0,2$ мас. \%. Микроэлементный состав пород определялся методом ICP MS на квадрупольном масс-спектрометре ELAN 9000 Perkin Elmer в ЦКП «Геоаналитик» Института геологии и геохимии УрО РАН (Екатеринбург). Разложение образцов пород, в зависимости от их состава, проводили путём кислотного вскрытия как в открытой, так и в закрытой системах. При построении калибровочных графиков использовались государственные стандартные образцы магматических пород с аттестованными содержаниями элементов.

\section{Краткая геологическая характеристика объекта исследований}

Продукты вулканизма берёзовской и греховской свит развиты в осевой части Магнитогорской мегазоны (рис. 1a), соответствующей так называемому Магнитогорско-Богдановскому грабену [7].

Берёзовская свита $\left(\mathrm{C}_{1} \mathrm{t}_{2}-\mathrm{V}_{1}\right)$ впервые была выделена
Л. С. Либровичем в береговом разрезе р. Урал близ пос. Берёзовский [2]. Она представлена контрастно дифференцированными базальт-риолитовыми толщами, перемежающимися с различными по составу вулканокластическими и терригенными отложениями [8]. Вулканиты берёзовской свиты являются продуктами извержений стратовулканов и залегают в виде лавовых потоков, покровов и куполов. На рис. 16 показан представительный разрез базальтов берёзовской свиты близ п. Кирса Челябинской области. Соотношения пород основного, среднего и кислого состава составляют 37/26/37. Мощность свиты достигает 1500 м.

Греховская свита $\left(\mathrm{C}_{1} \mathrm{v}_{1}-\mathrm{v}_{2}\right)$ «выделена» В. М. Мосейчуком с соавторами из берёзовской свиты [9]. Она согласно залегает на берёзовской свите [10] и также сложена вулканогенным, вулканокластическим, терригенным, терригенно-карбонатным материалом. Вулканиты являются продуктами трещинных извержений, приуроченных к структурам северо-восточного направления. Породы залегают в виде быстро выклинивающихся лавовых потоков, кислые образования встречаются в виде экструзивных тел. На рис. 1в показан представительный разрез базальтов греховской свиты на левом берегу р. Урал близ п. Грязнушинский. Соотношения пород основного, среднего и кислого состава составляют 68/20/12. Мощность свиты варьирует в больших пределах - 100-3300 м.

\section{Петрография}

Вулканиты основного состава представленных свит по петрографическим особенностям мало отличаются друг от друга. Это в разной степени метасоматизированные порфировые, реже афировые базальты. Последние разновидности чаще наблюдаются среди вулканитов греховской свиты. Также установлено, что в базальтах берёзовской свиты чаще встречается пилотакситовая структура основной массы (рис. 2a), а в породах греховской свиты - с одинаковой частотой и интерсертальная (рис. 2б), и пилотакситовая структура. Порфировые вкрапленники чаще всего представлены основным плагиоклазом, но иногда оливином и пироксеном (ромбическим или моноклинным) (рис. 2в). Количество порфировых вкрапленников в неафировых породах варьирует от 5 до $15 \%$, размеры некоторых кристаллов достигают 6,5 мм. В наиболее мощных лавовых потоках встречаются полнокристаллические породы - порфировидные пойкилоофитовые долериты, содержащие оливин в количестве до $17 \%$ (рис. 2г).

Плагиоклаз является главным минералом во всех типах базальтов, слагая 75-85 об. \%. Клинопироксен составляет 1-5 \%, ортопироксен - до $10 \%$, оливин до $7 \%$, амфибол - до $2 \%$, биотит - 0-5\%, вулканическое стекло - 1-30\%. Среди акцессорных минералов наиболее характерны титаномагнетит (1-4 \%), образующий либо относительно крупные идиоморфные зёрна (вкрапленники), либо рассредоточенную в основной массе тонкодисперсную вкрапленность (рис. 2д, ж), а также апатит (<1\%), встречающийся как в 


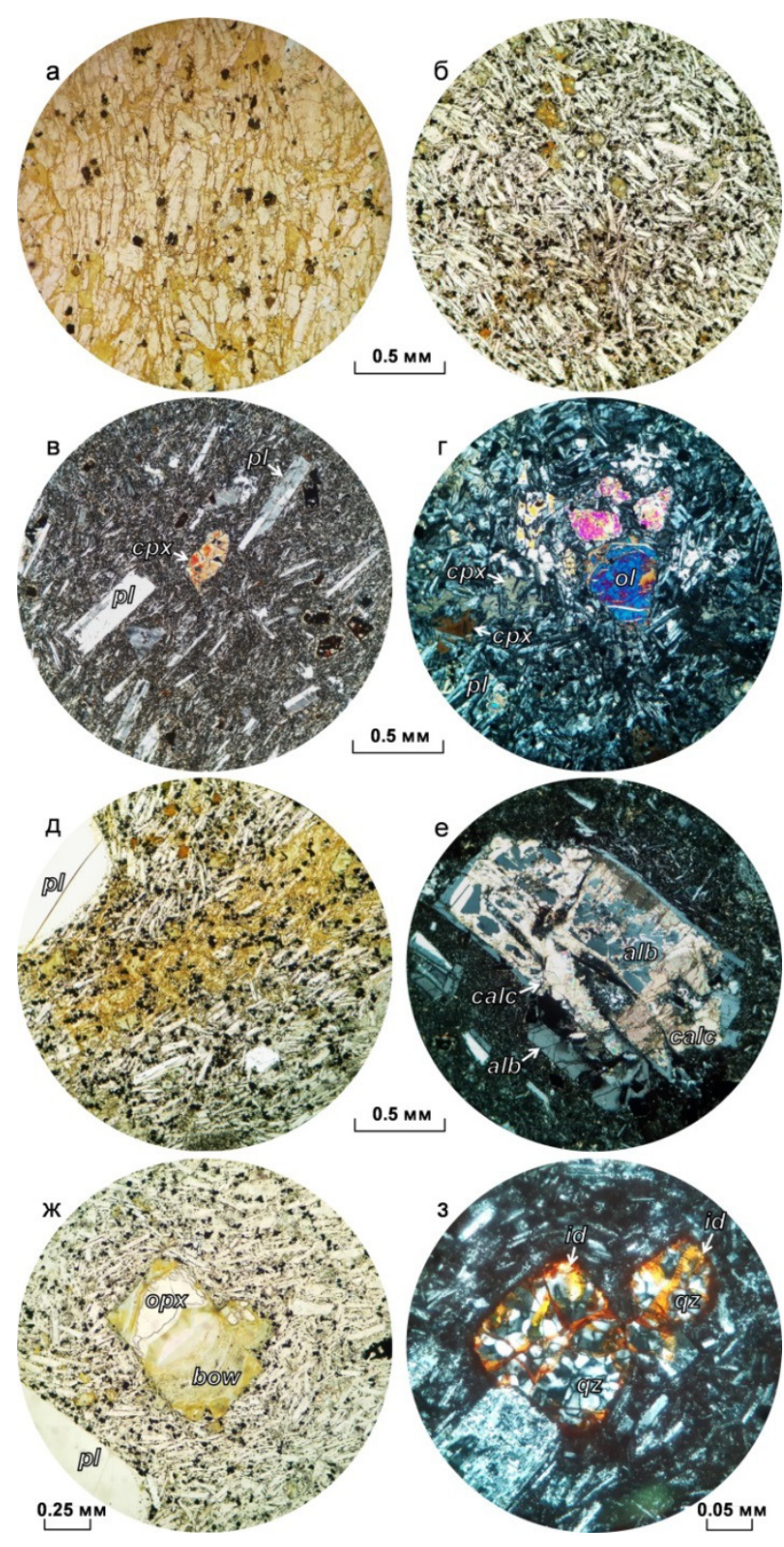

Pис. 2. Фотографии шлифов базальтоидов берёзовской и греховской свит: $a$ - пилотакситовая структура основной массы, $\sigma$ - интерсертальная структура основной массы, $в$ - пироксен-плагиоклазовый порфирит, 2 - порфировидный оливиновый долерит, $\partial$ - жиловидный метасоматический ореол в основной массе базальта, $e$ - замещённый альбитом и кальцитом вкрапленник плагиоклаза в базальте, ж - замещённый боулингитом вкрапленник ортопироксена в базальте, з - окварцевание псевдоморфоз иддингсита по оливину в базальте; $a, \sigma$, $\partial$, ж-проходящий свет без анализатора, 6 , г, е , з - с анализатором.

Примечание: alb - альбит, bow - боулингит, calc - кальцит, $c p x$ - клинопироксен, $i d$ - иддингсит, opx - ортопироксен, $p l$ плагиоклаз, $q z-$ кварц.

промежутках между лейстами плагиоклаза, так и в виде твёрдых включений внутри фенокристаллов плагиоклаза.

Вторичные изменения эффузивов связаны с окварцеванием, карбонатизацией, а также с калий-натровым (калишпат, альбит) и магний-железистым (хло- риты, амфиболы, слюды, серпентин, смектиты, эпидот, гидроокислы железа) метасоматозом. В некоторых образцах пород продукты $\mathrm{Mg}-\mathrm{Fe}$ метасоматоза прослеживаются в виде жиловидных ореолов (рис. 2д). Плагиоклаз обычно замещается альбитом, калишпатом, гидрослюдами, кальцитом (рис. 2е). Клинопироксен часто хлоритизирован или уралитизирован, а ортопироксен замещён жёлто-зелёным боулингитом (смесью серпентина, хлорита, монтмориллонита) (рис. 2ж). Оливин обычно превращён в краснокоричневый иддингсит (смесь смектита, хлорита, серпентина, гётита). В некоторых сильно изменённых породах можно выделить не менее двух этапов метасоматизации, что выражается, к примеру, в окварцевании псевдоморфоз иддингсита по оливину (рис. 2з).

Степень изменённости. Для удобства использования результатов петрографических исследований базальтоидов при интерпретации син- и постмагматических процессов была использована шкала метасоматической преобразованности пород - степень изменённости (СИ). СИ меняется от 0 до 3, где 0 - неизменённые породы; 1 - мало изменённые породы, в которых первичные минералы незначительно замещены вторичными (по краям или по трещинам); 2 - существенно изменённые породы, в которых первичные минералы на 50 \% и более замещены вторичными; 3 сильно изменённые породы, в которых первичные минералы практически нацело замещены вторичными (псевдоморфно), но магматическая структура определяется без особого труда. Породы, в которых первичная структура неопределима, по всей видимости, следует относить к метаморфическим.

\section{Петрогеохимия}

Среди изученных образцов базальтоидов неизменённых разновидностей не было обнаружено. По СИ выделены 1, 2 и 3 группы образцов. На серии диаграмм (рис. 3) приведены содержания основных петрогенных оксидов в породах этих выделенных групп. На большинстве графиков наблюдается увеличение разброса значений в уровне концентраций петрохимических элементов с увеличением СИ пород (1-2-3). Наиболее стабильными являются $\mathrm{TiO}_{2}$ и $\mathrm{Al}_{2} \mathrm{O}_{3}$. Однако при всём этом средние содержания многих макроэлементов $\left(\mathrm{TiO}_{2}, \mathrm{Al}_{2} \mathrm{O}_{3}, \mathrm{FeO}_{\mathrm{t}}, \mathrm{MgO}, \mathrm{Na}_{2} \mathrm{O}, \mathrm{K}_{2} \mathrm{O}, \mathrm{P}_{2} \mathrm{O}_{5}\right)$ в породах разной СИ очень близки. Зафиксировано некоторое увеличение средних концентраций $\mathrm{SiO}_{2}$ во 2 и 3 группах образцов - 52 мас. \% против $48 \%$ в 1 группе, а также уменьшение содержаний $\mathrm{MgO}-6 \%$ против $7 \%$, соответственно. Но уровни концентраций $\mathrm{CaO}$ и величина $\mathrm{Fe}^{3+} / \mathrm{Fe}^{3+}$ различаются значительно. Так, средние содержания $\mathrm{CaO}$ в породах 1 группы $(8,4$ мас. \%) в два раза выше, чем в породах 2 (4,2\%) и 3 групп (4,3\%). $\mathrm{Fe}_{2} \mathrm{O}_{3} / \mathrm{FeO}$ отношения в образцах с $\mathrm{CИ}$ $=1,2$ и 3 составляют в среднем $0,8,1,1$ и 4,5, но общая сумма $\mathrm{Fe}_{2} \mathrm{O}_{3}+\mathrm{FeO}=\mathrm{FeO}_{\mathrm{t}}$ сопоставима во всех группах (11,1-12,5 \%). Таким образом, использование аналитических данных о химическом составе исследуемых пород для петролого-геохимических рекон- 


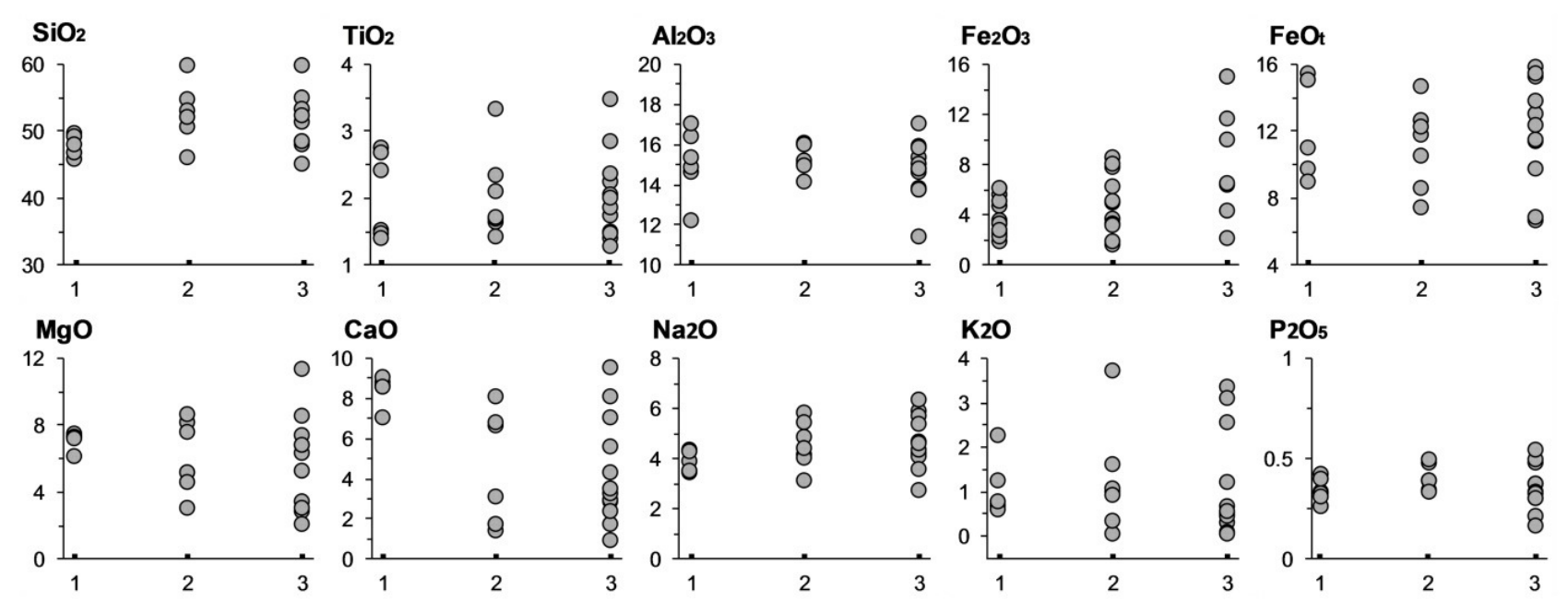

Рис. 3. Содержание петрогенных оксидов в различных по степени изменённости базальтоидах берёзовской и греховской свит.

струкций вполне допустимо, но при условии достаточного количества проб с каждого разреза. Анализы $\mathrm{SiO}_{2}$ и $\mathrm{MgO}$ следует применять с осторожностью, а содержания $\mathrm{CaO}$ лучше не использовать. По всей видимости, при замещении плагиоклаза вторичными продуктами в процессе метасоматизации базальтоидов, происходил существенный вынос кальция. Окварцевание пород предположительно связано с привнесением кремнезёма из вмещающих пород. Остальные макрокомпоненты рассматриваемой постмагматической системы перераспределялись внутри изверженного тела за счёт их рециркуляции, т.е. автономного метасоматоза. Резкое увеличение $\mathrm{Fe}_{2} \mathrm{O}_{3} / \mathrm{FeO}$ сигнализирует об окисленном характере гидротермального флюида [11].

На петрохимической классификационной диаграмме для вулканитов фигуративные точки берёзовской и греховской свит ложатся в область субщелочной серии (рис. 4). Большая часть точек составов пород (особенно мало изменённых) обеих свит тяготеет к полю трахибазальтов. В остальном по петрохимическим характеристикам эти свиты несколько различаются. Так, базальтоиды греховской свиты отличаются гораздо более высокой титанистостью $\left(\mathrm{TiO}_{2} \approx 2,7 \%\right)$ в сравнении с берёзовской $\left(\mathrm{TiO}_{2} \approx 1,4 \%\right)$. К тому же, породы греховской свиты существенно более железистые (13\% против $9 \%$ ), а также менее глинозёмистые (15,2\% против $16,3 \%$ и менее калиевые (1,0\% против 1,4\%). Индекс магнезиальности $\mathrm{Mg \#}\left(100 \times \mathrm{MgO} /\left(\mathrm{FeO}_{\mathrm{t}}+\mathrm{MgO}+\mathrm{MnO}\right)\right)$ в базитах берёзовской свиты в среднем равен 45,7, а в греховской - 32,2. По типу щёлочности $(\mathrm{Na} / \mathrm{K})$ берёзовские породы относятся к калий-натриевому, а греховские - к натриевому ряду. Валовый химический состав пород представлен в таблице.

Микроэлементный состав исследуемых базальтоидов характеризуется высокими концентрациями ряда крупноионных литофильных (Ba, Th, $\mathrm{U}, \mathrm{Pb}, \mathrm{Sr})$ и высокозарядных (Zr, Hf, Y, REE) элементов. На спайдердиаграмме (рис. 5a) спектры распределения индика-

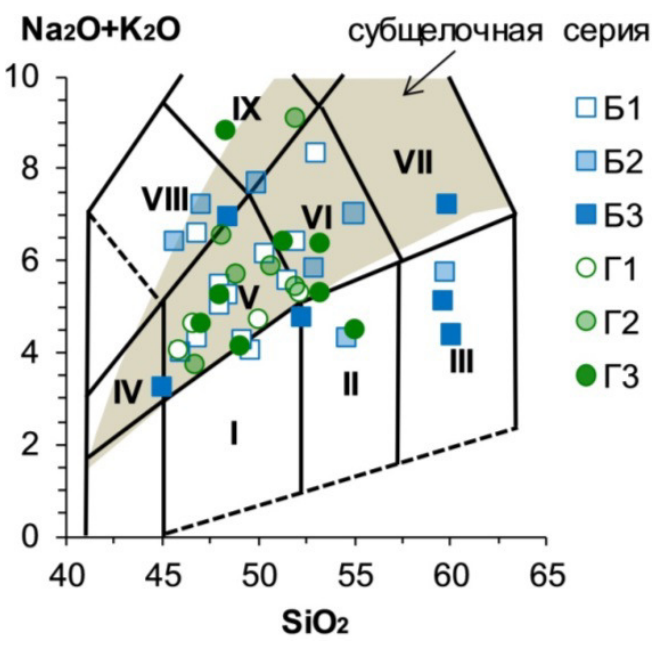

Puc. 4. Классификационная TAS-диаграмма для базальтоидов берёзовской (Б1-3) и греховской (Г1-3) свит: $I$ поле базальтов, II - поле андезибазальтов, III - поле андезитов, IV - поле умереннощелочных пикробазальтов, V - поле трахибазальтов, VI - поле трахиандезибазальтов, VII - поле трахиандезитов, VIII - поле щелочных базальтов, IX - поле фонотефритов. Область субщелочной серии по [12]. Примечание: индексы 1, 2, 3 соответствуют степеням изменённости пород.

торных элементов в породах берёзовской и греховской свит близки между собой, располагаясь между линиями составов базальтов островных дуг, океанических островов и внутриконтинентальных рифтов. Изучаемые вулканиты по уровню накопления высокозарядных элементов схожи с базальтами океанических островов (кроме $\mathrm{Nb}$ и Та), отличаясь более высокими содержаниями крупноионных литофильных элементов, но обычно не достигающими уровня базальтов внутриконтинентальных рифтов. От базальтов островных дуг породы берёзовской и греховской свит отличаются ещё значительнее, превышая уровни концентраций многих крупноионных и высокозарядных элементов (кроме $\mathrm{Cs}, \mathrm{Sr}$ ). Весьма примечательной особенностью изучаемых образований является 
Таблица

Содержание петрогенных (мас. \%) и примесных (2/m) элементов

в характерных пробах базальтоидов берёзовской и греховской свит

\begin{tabular}{|c|c|c|c|c|c|c|c|c|c|c|c|c|c|c|c|}
\hline & \multicolumn{8}{|c|}{ Берёзовская свита } & \multicolumn{7}{|c|}{ Греховская свита } \\
\hline \multirow{2}{*}{$\begin{array}{c}\text { СИ } \\
\text { № обр. }\end{array}$} & \multicolumn{2}{|c|}{1} & \multicolumn{3}{|c|}{2} & \multicolumn{3}{|c|}{3} & \multicolumn{2}{|c|}{1} & \multicolumn{2}{|c|}{2} & \multicolumn{3}{|c|}{3} \\
\hline & $81 / 09$ & $337 / 10$ & $316 / 10$ & $330 / 10$ & $332 / 10$ & $315 / 10$ & $317 / 10$ & $340 / 10$ & $70 / 09$ & $71 / 09$ & $272 / 10$ & $335 / 10$ & $267 / 10$ & $268 / 10$ & $269 / 10$ \\
\hline $\mathrm{SiO}_{2}$ & 49,65 & 49,18 & 59,71 & 54,61 & 52,88 & 52,28 & 59,85 & 59,67 & 46,62 & 45,83 & 50,69 & 51,99 & 55,00 & 53,18 & 51,30 \\
\hline $\mathrm{TiO}_{2}$ & 1,51 & 1,48 & 1,42 & 1,69 & 1,70 & 1,50 & 1,40 & 1,46 & 2,74 & 2,68 & 3,31 & 2,34 & 2,36 & 2,84 & 3,47 \\
\hline $\mathrm{Al}_{2} \mathrm{O}_{3}$ & 16,38 & 15,30 & 16,09 & 15,15 & 14,16 & 13,69 & 15,81 & 17,03 & 14,64 & 14,87 & 15,01 & 14,93 & 15,36 & 15,86 & 13,85 \\
\hline $\mathrm{FeOt}$ & 9,69 & 10,97 & 8,61 & 10,48 & 11,74 & 15,43 & 6,60 & 9,77 & 15,40 & 15,08 & 14,63 & 12,59 & 15,78 & 15,27 & 17,44 \\
\hline $\mathrm{MnO}$ & 0,10 & 0,17 & 0,18 & 0,08 & 0,08 & 0,16 & 0,11 & 0,05 & 0,19 & 0,19 & 0,15 & 0,13 & 0,07 & 0,07 & 0,07 \\
\hline $\mathrm{MgO}$ & 7,47 & 7,24 & 3,00 & 8,12 & 8,66 & 6,77 & 5,21 & 2,99 & 6,14 & 7,41 & 5,10 & 4,57 & 2,80 & 2,06 & 3,44 \\
\hline $\mathrm{CaO}$ & 8,82 & 9,05 & 1,73 & 1,43 & 1,72 & 0,93 & 1,72 & 3,45 & 8,63 & 8,57 & 3,05 & 6,81 & 2,84 & 2,90 & 3,21 \\
\hline $\mathrm{Na}_{2} \mathrm{O}$ & 3,47 & 3,50 & 4,12 & 4,00 & 4,85 & 4,36 & 4,67 & 59 & 3,91 & 3,40 & 5,84 & 4,37 & 4,20 & 5,89 & 6,34 \\
\hline $\mathrm{K}_{2} \mathrm{O}$ & 0,60 & 0,75 & 1,62 & 0,33 & 0,99 & 0,42 & 2,55 & 0,54 & 0,69 & 0,66 & 0,03 & 1,06 & 0,30 & 0,49 & 0,08 \\
\hline $\mathrm{P}_{2} \mathrm{O}_{5}$ & 0,26 & 0,31 & 0,34 & 0,38 & 0,50 & 0,30 & 0,33 & 0,21 & 0,33 & 0,33 & 0,39 & 0,39 & 0,48 & 0,49 & 0,54 \\
\hline ППП & 2,92 & 2,72 & 2,51 & 3,77 & 3,37 & 4,76 & 2,62 & 1,20 & 1,72 & 83 & 3,08 & 1,61 & 1,50 & 1,93 & 1,22 \\
\hline Сумма & 100,87 & 100,66 & 99,33 & 100,04 & 100,65 & 100,60 & 100,88 & 100,96 & 101,02 & 100,85 & 101,29 & 100,79 & 100,69 & 100,99 & 100,94 \\
\hline $\mathrm{Li}$ & 3,13 & 12,23 & 10,76 & 8,55 & 11,48 & 16,37 & 8,60 & 12,04 & 12,28 & 11,54 & 9,60 & 7,76 & 3,07 & 4,69 & 2,88 \\
\hline $\mathrm{Sc}$ & 20,88 & 22,18 & 11,79 & 12,12 & 12,45 & 10,49 & 10,35 & 12,70 & 26,94 & 25,61 & 33,04 & 23,20 & 26,06 & 34,26 & 24,20 \\
\hline $\mathrm{V}$ & 172,61 & 207,29 & 76,29 & 66,33 & 71,22 & 77,72 & 70,79 & 141,99 & 194,97 & 190,30 & 371,73 & 209,60 & 334,47 & 312,00 & 314,59 \\
\hline $\mathrm{Cr}$ & 108,01 & 206,93 & 4,83 & 3,03 & 23,75 & 11,70 & 4,11 & 39,07 & 42,40 & 40,97 & 19,26 & 59,05 & 28,92 & 218,60 & 46,87 \\
\hline Co & 33,38 & 36,27 & 8,89 & 8,32 & 9,71 & 11,18 & 7,12 & 12,07 & 37,81 & 37,31 & 22,38 & 36,28 & 12,86 & 14,59 & 14,19 \\
\hline $\mathrm{Ni}$ & 81,10 & 201,21 & 4,66 & 1,20 & 9,95 & 5,62 & 1,71 & 102,15 & 38,86 & 36,62 & 11,61 & 43,70 & 9,51 & 166,56 & 27,04 \\
\hline $\mathrm{Cu}$ & 23,59 & 29,67 & 13,50 & 15,29 & 30,00 & 12,73 & 13,24 & 121,90 & 51,04 & & 35,82 & 34,78 & 38,83 & 35,23 & 35,74 \\
\hline $\mathrm{Zn}$ & 66,01 & 56,26 & 68,05 & 61,43 & 66,59 & 70,03 & 61,07 & 38,24 & 99,05 & 94,08 & 97,90 & 136,44 & 41,77 & 39,87 & 57,70 \\
\hline $\mathrm{Ga}$ & 16,50 & 17,16 & 24,31 & 19,38 & н,д, & 19,40 & 18,79 & 17,17 & 20,81 & 19,51 & 22,78 & 19,73 & 10,85 & 15,56 & 14,35 \\
\hline $\mathrm{Rb}$ & 3,38 & 9,82 & 14,80 & 6,94 & 18,07 & 8,90 & 50,76 & 6,97 & 3,79 & 4,4 & 0,90 & 15,28 & 0,49 & 9,80 & 0,61 \\
\hline $\mathrm{Sr}$ & 397,59 & 405,21 & 212,22 & 205,60 & 215,34 & 76,04 & 261,15 & 368,11 & 377,64 & 344,60 & 54,90 & 382,17 & 147,96 & 179,28 & 75,98 \\
\hline Y & 20,50 & 18,35 & 33,00 & 37,45 & 34,43 & 36,47 & 33,49 & 18,04 & 29,21 & 28,16 & 46,37 & 36,36 & 33,17 & 32,38 & 30,36 \\
\hline $\mathrm{Zr}$ & 135,11 & 111,56 & 237,16 & 248,83 & 233,69 & 242,49 & 229,01 & 133,81 & 177,18 & 170,54 & 235,19 & 220,70 & 177,50 & 169,22 & 186,76 \\
\hline $\mathrm{Nb}$ & 5,83 & 5,34 & 9,86 & 10,69 & 10,58 & 10,25 & 9,88 & 8,33 & 13,40 & 12,69 & 9,18 & 10,33 & 6,85 & 5,75 & 7,31 \\
\hline Cs & 0,06 & 0,19 & 0,20 & 0,08 & 0,18 & 0,27 & 0,17 & 0,17 & 0,44 & 0,59 & 0,02 & 0,31 & 0,15 & 0,21 & 0,03 \\
\hline $\mathrm{Ba}$ & 218,26 & 247,69 & 172,10 & 60,98 & 139,88 & 43,41 & 423,91 & 428,18 & 134,57 & 121,60 & 15,23 & 551,07 & 43,91 & 176,63 & 34,50 \\
\hline $\mathrm{La}$ & 12,31 & 12,34 & 10,07 & 25,23 & 22,24 & 14,42 & 19,99 & 15,52 & 14,63 & 13,61 & 17,73 & 20,71 & 12,75 & 11,49 & 8,90 \\
\hline $\mathrm{Ce}$ & 29,25 & 28,87 & 25,15 & 57,58 & 52,31 & 36,23 & 44,95 & 33,77 & 37,51 & 35,56 & 57,75 & 50,46 & 31,12 & 30,08 & 25,48 \\
\hline $\operatorname{Pr}$ & 3,68 & 3,71 & 3,72 & 7,27 & 6,86 & 4,76 & 5,72 & 4,25 & 4,99 & 4,73 & 8,06 & 6,64 & 4,40 & 4,43 & 3,94 \\
\hline $\mathrm{Nd}$ & 16,04 & 15,64 & 17,43 & 30,81 & 29,84 & 20,89 & 23,83 & 17,27 & 22,98 & 21,90 & 36,51 & 29,51 & 20,53 & 20,45 & 19,76 \\
\hline $\mathrm{Sm}$ & 3,90 & 3,63 & 4,77 & 7,36 & 7,01 & 5,14 & 5,78 & 3,91 & 5,76 & 5,52 & 9,15 & 7,14 & 5,50 & 5,77 & 5,46 \\
\hline $\mathrm{Eu}$ & 1,38 & 1,38 & 1,30 & 2,64 & 2,48 & 1,18 & 1,84 & 1,39 & 2,06 & 1,93 & 4,07 & 2,34 & 1,91 & 2,04 & 2,02 \\
\hline $\mathrm{Gd}$ & 4,06 & 4,31 & 5,46 & 8,00 & 7,72 & 6,31 & 6,51 & 4,44 & 5,93 & 5,88 & 10,28 & 7,86 & 6,58 & 6,51 & 6,09 \\
\hline $\mathrm{Tb}$ & 0,64 & 0,60 & 0,88 & 1,19 & 1,14 & 1,04 & 0,98 & 0,62 & 0,93 & 0,91 & 1,42 & 1,15 & 0,99 & 1,03 & 0,93 \\
\hline Dy & 4,24 & 3,53 & 5,66 & 7,29 & 6,97 & 7,20 & 6,32 & 3,56 & 6,15 & 5,94 & 9,02 & 7,28 & 6,44 & 6,34 & 6,11 \\
\hline Ho & 0,85 & 0,71 & 1,25 & 1,54 & 1,46 & 1,57 & 1,35 & 0,72 & 1,25 & 1,18 & 1,88 & 1,51 & 1,36 & 1,32 & 1,25 \\
\hline Er & 2,37 & 2,05 & 3,84 & 4,44 & 4,23 & 4,62 & 4,02 & 2,02 & 3,34 & 3,25 & 5,42 & 4,41 & 3,90 & 3,70 & 3,58 \\
\hline $\mathrm{Tm}$ & 0,35 & 0,29 & 0,57 & 0,64 & 0,59 & 0,66 & 0,59 & 0,28 & 0,48 & 0,46 & 0,77 & 0,63 & 0,55 & 0,52 & 0,50 \\
\hline $\mathrm{Yb}$ & 2,22 & 1,89 & 3,81 & 4,04 & 3,91 & 4,32 & 4,04 & 1,79 & 3,01 & 2,95 & 4,99 & 4,07 & 3,59 & 3,38 & 3,25 \\
\hline $\mathrm{Lu}$ & 0,33 & 0,27 & 0,59 & 0,62 & 0,57 & 0,64 & 0,61 & 0,2 & 0,45 & 0,43 & 0,73 & 0,59 & 0,52 & 0,50 & 0,48 \\
\hline $\mathrm{Hf}$ & 3,02 & 2,60 & 5,81 & 6,48 & 6,21 & 6,99 & 6,45 & 3,48 & 3,98 & 3,91 & 6,43 & 5,95 & 4,89 & 4,18 & 5,14 \\
\hline $\mathrm{Ta}$ & 0,36 & 0,32 & 0,66 & 0,76 & 0,75 & 0,78 & 0,71 & 0,51 & 2,50 & 0,77 & 0,65 & 0,70 & 0,46 & 0,38 & 0,53 \\
\hline $\mathrm{Pb}$ & 3,59 & 3,97 & 2,72 & 1,52 & н,Д, & 1,04 & 4,30 & 11,37 & 2,53 & 1,61 & 2,69 & 7,87 & 2,84 & 1,80 & 3,08 \\
\hline Th & 1,69 & 1,56 & 5,78 & 5,34 & 5,28 & 6,61 & 5,92 & 3,70 & 0,95 & 0,88 & 2,66 & 3,40 & 1,25 & 1,39 & 0,93 \\
\hline $\mathrm{U}$ & 0,64 & 0,64 & 2,85 & 1,76 & 1,69 & 3,03 & 2,76 & 0,54 & 0,40 & 0,38 & 1,17 & 1,24 & 0,64 & 0,89 & 0,58 \\
\hline
\end{tabular}

Примечание: СИ - степень изменённости пород.

положительная аномалия свинца. Между собой базиты берёзовской и греховской свит, кроме содержаний титана, различаются по более высокому уровню концентраций в последнем комплексе ряда переходных элементов ( $\mathrm{Sc}, \mathrm{V}, \mathrm{Cr}, \mathrm{Zn}$ ). Распределение РЗЭ в породах слабо дифференцировано: $(\mathrm{La} / \mathrm{Yb})_{\mathrm{N}}=3.8$ в берёзовской свите и $(\mathrm{La} / \mathrm{Yb})_{\mathrm{N}}=3.2$ в греховской свите. Европиевая аномалия практически не выражена. 


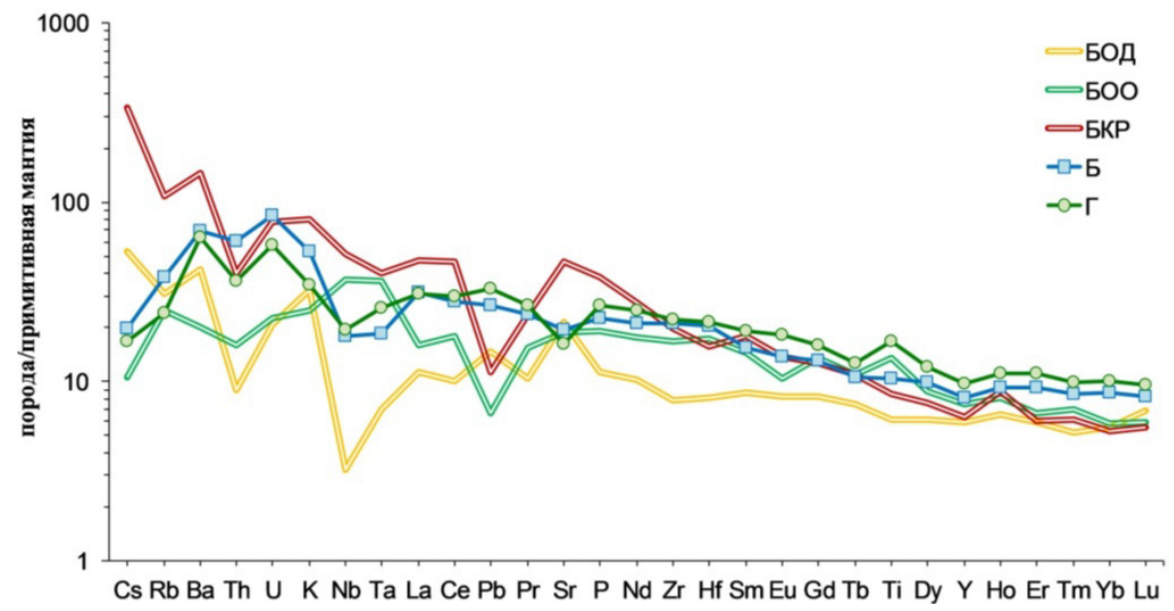

Puc. 5. Мультиэлементная диаграмма для средних составов базальтов берёзовской (Б) и греховской (Г) свит, а также базальтов островных дуг (БОД), базальтов океанических островов (БОО) и базальтов континентальных рифтов (БКР) по [13]. Состав примитивной мантии по [14].

Обсуждение результатов

Палеотектонические реконструкции Южного Урала указывают на завершение субдукционного этапа в Магнитогорской мегазоне уже в позднем девоне [15, 16]. Дальнейшее её развитие связывается с заложением рифта, или серии грабенов при косой коллизии Магнитогорской островной дуги и окраины ВосточноЕвропейского континента $[4,10,17]$. Однако для объяснения специфических геохимических особенностей раннекаменноугольных вулканитов Магнитогорской мегазоны привлекались совершенно разные геодина- мические гипотезы, в том числе предполагающие участие мантийных плюмов $[5,15,17,18]$. Геологические условия развития пород берёзовской и греховской свит, а также особенности их химического состава, свидетельствуют об их генетическом родстве. Учитывая их пространственную и возрастную близость, оба комплекса, вероятно, сформировались из единого магматического очага, но претерпевшего несколько разные эволюционные процессы во времени и на пути к извержению вулканического материала. На рис. 6 приведены диаграммы отношений несовместимых
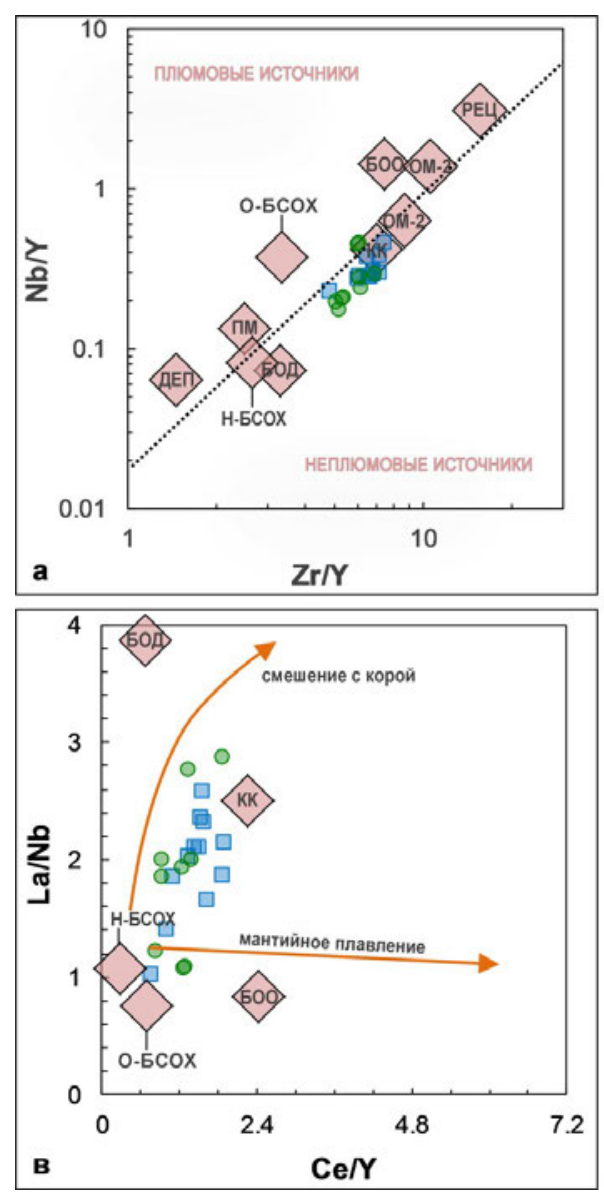
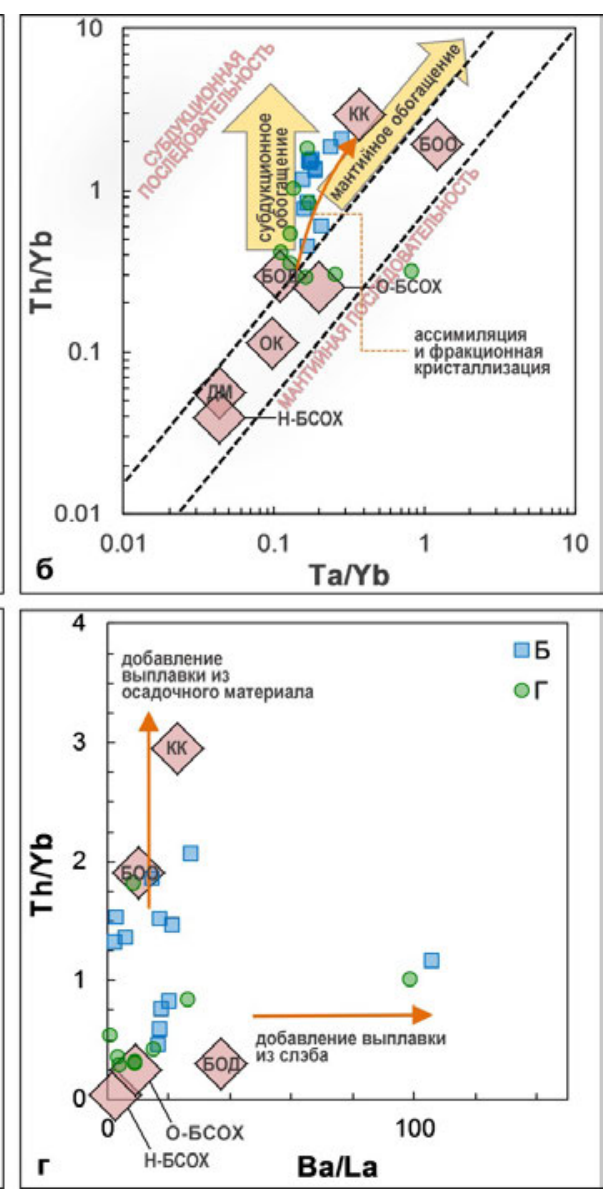

Рис. 6. Геохимические диаграммы для базальтоидов берёзовской (Б) и греховской (Г) свит: $a-\mathrm{Zr} / \mathrm{Y}-\mathrm{Nb} / \mathrm{Y}$ по [21], $\sigma-\mathrm{Ta} / \mathrm{Yb}-\mathrm{Th} / \mathrm{Yb}$ по [22], в$\mathrm{Ce} / \mathrm{Y}-\mathrm{La} / \mathrm{Nb}$ по [23], $2-\mathrm{Ba} / \mathrm{La}-$ $\mathrm{Th} / \mathrm{Yb}$ по [24].

Примечание: Н-БСОХ средний состав базальтов срединно-океанических хребтов, $O$ БСОХ - средний состав обогащённых базальтов срединноокеанических хребтов, БОО средний состав базальтов океанических островов, БОД - средний состав базальтов островных дуг, $K K$ - средний состав континентальной коры, $O K$ - средний состав океанической коры, ДМмалоглубинная деплетированная мантия, ПМ - примитивная мантия, $O M-1$ и $O M-2$ - обогащённая мантия, ДЕП - глубинная деплетированная мантия, РЕЦ рециклированная литосфера. 
элементов, позволяющие понять основные направления геохимической эволюции магматического расплава этих базальтов. На диаграмме $\mathrm{Zr} / \mathrm{Y}-\mathrm{Nb} / \mathrm{Y}$ (рис. 6а) фигуративные точки берёзовских и греховских вулканитов попадают в область неплюмовых мантийных источников, образуя рой вблизи среднего состава континентальной коры и обогащённого мантийного источника типа ЕM2, возникающего за счёт добавления к мантийным выплавкам терригенного материала при субдуцировании океанической плиты [19], либо при плавлении древней метасоматизированной океанической литосферы [20].

На диаграмме $\mathrm{Ta} / \mathrm{Yb}-\mathrm{Th} / \mathrm{Yb}$ (рис. 6б) точки составов основных пород берёзовской и греховской свиты выстраиваются вдоль тренда эволюции расплава, претерпевшего процессы ассимиляции и кристаллизационной дифференциации. Значительное влияние процессов коровой контаминации на геохимию изучаемых вулканитов демонстрирует диаграмма $\mathrm{Ce} / \mathrm{Y}-$ $\mathrm{La} / \mathrm{Nb}$ (рис. 6в), где фигуративные точки образуют тренд смешения мантийного расплава с коровым материалом. Диаграмма $\mathrm{Ba} / \mathrm{La}-\mathrm{Th} / \mathrm{Yb}$ (рис. 6г) указывает на то, что в исходном расплаве присутствовал осадочный материал, о чём свидетельствует распределение точек составов берёзовских и греховских базальтоидов в направлении тренда добавления выплавок осадочного происхождения. Две фигуративные точки, резко смещённые в сторону тренда добавления выплавок из слэба, принадлежат сильно изменённым образцам базальтов, претерпевшим неравномерную калишпатизацию.

Как было отмечено выше, исследуемым вулканитам свойственно умеренное $(\mathrm{La} / \mathrm{Yb})_{\mathrm{N}}=3-4$, а также умеренные значения $\mathrm{Lu} / \mathrm{Hf}=0,1$, характеризующие глубину источника плавления чуть выше уровня гранат-содержащей перидотитовой мантии [25].

Таким образом, анализ распределения фигуративных точек на представленных диаграммах рис. 6 показывает, что базальтоиды берёзовской и греховской свит являются производными обогащённого осадочным материалом мантийного источника. На пути к продвижению к дневной поверхности магматический расплав, вероятно, ассимилировал вмещающие породы островодужной коры, а также претерпел кристаллизационную дифференциацию в промежуточных камерах. Последнее обстоятельство в большей степени касается эффузивов берёзовской свиты, извергавшихся из вулканов центрального типа. Вулканиты берёзовской и греховской свит от океанических плюмовых базальтов отличаются низкими концентрациями ниобия и тантала, а также крайне высоким содержанием свинца. Такие геохимические характеристики изучаемых базальтоидов могли быть связаны с вовлечением в зону плавления при субдукции утонённого края Восточно-Европейского континента [16]. Процесс субдукции континентальной коры, к примеру, последнее время применяется в модели формирования аккреционно-коллизионной структуры Северного Тибета [26]. Базальтоиды греховской свиты отлича- ются от берёзовской свиты высокой титанистостью и железистостью, а также низкой глинозёмистостью, магнезиальностью и калиевостью. Эти особенности свидетельствуют, во-первых, о большей выраженности процессов дифференциации расплава для берёзовской свиты, и во-вторых, о большем вовлечении в процессы плавления Ti-Fe-содержащих отложений для греховской свиты. В конечном итоге последнее обстоятельство могло служить причиной возникновения крупных Ti-Fe-месторождений Магнитогорского рудного района [27].

\section{Заключение}

Петрографические исследования раннекаменноугольных базальтоидов берёзовской и греховской свит Магнитогорской мегазоны показали, что породы в различной степени метасоматизированы. По составу минеральных ассоциаций можно выделить магниевожелезистый (хлориты, амфиболы, серпентин, гётит), калий-натриевый (альбит, калишпат), карбонатный (кальцит) и кремнёвый метасоматоз (кварц). По степени изменённости были выделены 3 группы образцов от мало- до сильно изменённых. Анализ петрохимического состава пород разной степени изменённости показал, что многие петрогенные элементы $\left(\mathrm{TiO}_{2}\right.$, $\mathrm{Al}_{2} \mathrm{O}_{3}, \mathrm{FeO}_{\mathrm{t}}, \mathrm{MgO}, \mathrm{Na}_{2} \mathrm{O}, \mathrm{K}_{2} \mathrm{O}, \mathrm{P}_{2} \mathrm{O}_{5}$ ) перераспределялись в изверженном теле за счёт их рециркуляции, что не изменяло средний состав пород. Некоторые элементы $\left(\mathrm{SiO}_{2}, \mathrm{MgO}\right)$ оказались более чувствительны к вторичным преобразованиям и для петрологических реконструкций их следует применять с осторожностью. Содержания $\mathrm{CaO}$ уменьшаются вдвое, в связи с чем анализы кальция в сильно изменённых породах для изучения магматизма неприменимы. Следует также осторожно применять анализы крупноионных литофильных микроэлементов ( $\mathrm{Ba}, \mathrm{Rb}, \mathrm{Sr})$, относящихся к высокомобильным элементам.

По химическому составу базальтоиды берёзовской и греховской свит относятся к субщелочной серии. Породы берёзовской свиты отличаются от греховской свиты пониженной титанистостью и железистостью, повышенной глинозёмистостью, магнезиальностью и калий-натриевым типом щёлочности вместо натриевого. Особенности распределения индикаторных микроэлементов в них схожи, базальтоиды характеризуются промежуточными геохимическими признаками между островодужными и внутриплитными океаническими базальтами.

Анализ петролого-геохимических диаграмм показал, что исследуемые базальтоиды являются производными обогащённого мантийного источника, близкого к типу ЕМ2. В расплаве присутствуют геохимические метки добавления выплавок терригенного материала, а также процессов кристаллизационной дифференциации и ассимиляции островодужной рамы. Резкая положительная аномалия свинца и повышенные содержания других коровых элементов могли быть связаны с вовлечением в процессы плавления утонённого края Восточно-европейского континента 
при сближении и последующей коллизии с ним Магнитогорской островной дуги. Высокая титанистость и железистость пород греховской свиты связывается с менее интенсивной дифференциацией магматического расплава и с присутствием в зоне плавления Ti-Feсодержащих терригенных отложений.

Работа выполнена в рамках государственного задания ИГ УФИЦ РАН по теме № 0252-2017-0012 «Магматические системы в истории развития Южного Урала (геодинамические обстановки формирования и металлогеническая специиализация)».

\section{ЛИТЕРАТУРА}

1. Салихов, Д. Н. Нижнекаменноугольный вулканизм Магнитогорского мегасинклинория / Д. Н. Салихов, А. В. Яркова. - Уфа, 1992. - 138 с.

2. Правикова, H. В. Раннекаменноугольный вулканизм Южного Урала : дис... канд. геол.-мин. наук : 25.00.01/ Правикова Наталья Витальевна; МГУ, 2006. - 173 с.

3. Фролова, Т. И. Геосинклинальный вулканизм (на примере восточного склона Южного Урала) / Т. И. Фролова, И. А. Бурикова. - М.: Изд-во МГУ, 1977. - 266 с.

4. Бочкарёв, В. В. Субщелочной магматизм Урала / В. В. Бочкарёв, Р.Г. Язева. - Екатеринбург: ИГГ УрО РАН, 2000. - 256 с. 5. Геодинамические обстановки формирования каменноугольных вулканических комплексов Южного Урала и Приуралья / А.В. Тевелев [и др.] // Очерки по региональной тектонике. - Т. 1: Южный Урал. - М.: Наука, 2005. - С. 213-247.

6. Ярошевский, А. А. Геохимическая структура раннекаменноугольных вулканических комплексов Южного Урала А. А. Ярошевский, А. В. Теваелев, И. А. Кошелева // Геохимия. -2007 . - № 7. - С. 718-732.

7. Каменноугольный вулкано-интрузивный магматизм Магнитогорско-Богдановского грабена в свете новых геолого-геохимических данных / Д. Н. Салихов [и др.] // Литосфера. - 2014. - №5. - С. 33-56.

8. Стратиграфические схемы Урала (докембрий, палеозой). - Екатеринбург. - 1993.

9. Государственная геологическая карта РФ масштаба 1:200 000 / В.М. Мосейчук [и др.] // Серия ЮжноУральская. Лист N-40-XXIV, N-40-XXX, Объясн. зап. Челябинск, 2000.

10. Вулканизм переходного этапа от позднедевонской островной дуги к раннекаменноугольным рифтам на Южном Урале / Н. В. Правикова [и др.] // Вестник МГУ. Серия 4. геология. - 2008. - №6. - С. 8-15.

11. Wood, S. A. Thermodynamic constraints on the solubility of platinum and palladium in hydrothermal solutions: reassessment of hydroxide, bisulfide, and ammonia complexing / S. A. Wood, B. W. Mountain // Economic geology. -1989. - V. 84. - P. 2020-2028.

12. Классификация и номенклатура магматических горных пород / Под ред. О. А. Богатикова, Е. Д. Андреева, М. Б. Бородаевской и др. - М.: Недра, 1981. - 160 с.

Институт геологии - обособленное структурное подразделение ФГУН Уфимского федерального исследовательского иентра Российской академии наук (ИГ УФИЦ РАН), Уфа Рахимов Ильдар Рашитович, кандидат геологоминералогических наук, старший научный сотрудник E-mail: rigel92@mail.ru; Тел.:+7(347)2728256

Салихов Делир Нурзадаевич, доктор геологоминералогических наук, главный научный сотрудник E-mail:magm@ufaras.ru; Tел.:+7(347)2728256
13. Средний состав магматических расплавов главных геодинамических обстановок по данным изучения расплавных включений в минералах и закалочных стекол / В. Б. Наумов [и др.] // Геохимия. - 2010. - № 12. - С. 1266-1288.

14. Lyubetskaya, T. Chemical composition of earth's primitive mantle and its variance / T. Lyubetskaya, J. Korenaga // Journal of geophysical research. -2007 . - V. 112. - P. 1-21.

15. Косарев, А. М. Петролого-геохимические особенности среднедевонско-раннекаменноугольных островодужных и коллизионных вулканитов Магнитогорской зоны в геодинамическом контексте / А. М. Косарев, В. Н. Пучков, И. Б. Серавкин // Литосфера. - 2006. - №1 - С. 3-21.

16. Пучков, B. Н. Геология Урала и Приуралья (актуальные вопросы стратиграфии, тектоники, геодинамики и металлогении) / В. Н. Пучков. - Уфа: ДизайнПолиграфСервис, 2010. $-280 \mathrm{c}$.

17. Arc-continent collision in the Southern Urals / D. Brown [et al.] // Earth-Science Reviews. - 2006. - V. 79. - P. 261-287.

18. Субдукция, коллизия и плюмы в эпоху позднепалеозойского магматизма Магнитогорской зоны Южного Урала / Д. Н. Салихов [и др.] // Литосфера. - 2019. - №2. - С.191-208.

19. Zindler, A. Chemical geodynamics / A. Zindler, S. Hart // Annual Reviews for Earth Planetary Sciences. - 1986. - V. 14. P. 493-571.

20. Recycled metasomatized lithosphere as the origin of the enriched mantle II (EM2) end-member: Evidence from the Samoan volcanic chain / R. K. Workman [et al.] // Geochemistry, Geophysics, Geosystems. - 2004. - V. 5. - No. 4. - 44 p.

21. Емельянова, Т. А. Геохимия и петрогенезис позднемезозойско-раннекайнозойских вулканитов Охотского и Японского окраинных морей / Т. А. Емельянова, Е. П. Леликов // Геохимия. - 2016. - № 6. - С. 525-535.

22. Quaternary post-collision alkaline volcanism NW of Ahar (NW Iran): Geochemical constraints of fractional crystallization process / R. Dabiri [et al.] // Geologica Carpathica. - 2011. - V. 62. - P. 547-562.

23. Hofmann, A. W. Mantle geochemistry: the message from oceanic volcanism / A. W. Hofmann // Nature. - 1997. - V. 385. - P. 219-229.

24. Silurian magmatism on the eastern margin of the Erguna Block, NE China: Evolution of the northern Great Xing'an Range / Z. Feng [et al.] // Gondwana Research. - 2018. - V. 61. - P. 46-62.

25. Geochemistry of lavas from the Emperor Seamounts, and the geochemical evolution of Hawaiian magmatism from 85 to $42 \mathrm{Ma} / \mathrm{M}$. Regelous [et al.] // Journal of Petrology. - 2003. V. 44. - No. 1. - P. 113-140.

26. Crust-mantle interaction in a continental subduction channel: evidence from orogenic peridotites in North Qaidam, Northern Tibet / R.X. Chen [et al.] // Journal of Petrology. 2017. - P. 1-36.

27. Рифтогенный магматизм и железооруденение Южного Урала / Г. Б. Ферштатер [и др.] // Геология рудных месторождений. - 2005. - Т. 47. - № 5. - С. 421-443.

Institute of Geology - Subdivision of the Ufa Federal Research Centre of the Russian Academy of Sciences (IG UFRC RAS),

Ufa, Russia

Rakhimov Ildar Rashitovich, Candidate of Geological and Mineralogical Sciences, Senior Researcher

E-mail: rigel92@mail.ru; Tel.: +7(347)2728256

Salikhov Delir Nurzadaevich, Doctor of Geological and Mineralogical Sciences, Chief Researcher

E-mail:magm@ufaras.ru; Tel.: +7(347) 2728256 